\title{
Historical declines of goliath grouper populations in South Florida, USA
}

\author{
Loren McClenachan*
}

Scripps Institution of Oceanography, 9500 Gilman Drive, La Jolla, California 92093-0208, USA

\begin{abstract}
Historical data are important in fisheries management and conservation, particularly for species which suffered significant population declines prior to the collection of ecological data. The globally endangered goliath grouper Epinephelus itajara was fished intensively long before data on population size were first collected. Historical population estimates have significant management implications, as the estimated time to full recovery depends on the size of the baseline population before depletion. Evidence used previously suggests that goliath grouper populations in Florida were reduced by as much as $95 \%$ relative to estimated baseline levels at the time of protection in 1990 and have since recovered to more than $30 \%$ of these values. However, actual historic abundances are not well known because few early data exist. I present 2 new data sets: (1) historical photographs of 'trophy fish' and (2) newspaper articles from the Florida Keys. I analyzed goliath grouper in photos taken of fish caught on Key West charter boats from 1956 to 1985 to assess changes in abundance before the fishery was closed in 1990. The average number of individuals displayed per trip decreased before 1960 and was reduced by $86 \%$ before 1979. Further evidence of declines is found in newspaper accounts of landings (1923 to 1977), which show decreases in the maximum individual fish size caught and the proportion of large grouper caught from land vs. offshore before 1950. These results demonstrate population declines over longer time scales than are currently considered and suggest that recent increases do not represent significant recovery compared to population abundances before depletion.
\end{abstract}

KEY WORDS: Historical ecology - Shifting baselines - Historical overfishing - Goliath grouper · Epinephelus itajara

Resale or republication not permitted without written consent of the publisher

\section{INTRODUCTION}

The degradation of marine ecosystems by overfishing over several human generations has resulted in lowered expectations for the natural abundances of marine animals and the value that marine ecosystems can provide to people (Pauly 1995, Jackson 1997, Dayton et al. 1998). Populations of marine fishes, turtles, and other large vertebrates that appear robust today are often small fractions of those observed by early explorers, naturalists, and fishermen (Jackson et al. 2001). When placed in a historical context, even populations that are considered depleted by modern standards are more severely reduced. Such shifting ecological baselines are difficult to quantify because historical data are sparse, typically qualitative, and not easily compared with modern fisheries and ecological data. Within the field of historical marine ecology, methods have been developed to integrate historical data into traditional ecological analyses in order to understand long-term trajectories of ecosystem change and the cumulative impacts that human activity has had on marine systems (e.g. Jackson et al. 2001, Baum et al. 2003, Myers \& Worm 2003, Pandolfi et al. 2003, Lotze \& Milewski 2004, Saenz-Arroyo et al. 2005, Lotze et al. 2006, McClenachan et al. 2006, Rosenberg et al. 2005, Ferretti et al. 2008, McClenachan \& Cooper 2008, Jackson 2008). Such analyses have become useful in assessing recovery and conservation status for marine animals around the world and are particularly relevant for the goliath grouper Epinephelus itajara in south Florida, USA.

Epinephelus itajara has been severely overfished throughout its range in both the tropical eastern Pacific and tropical western and eastern Atlantic, and is con- 
sidered to be Critically Endangered by the International Union for Conservation of Nature (IUCN 2007). In Florida, populations reached their lowest levels in the late 1980s, and a fishing moratorium was enacted in 1990 (NMFS 2006). Since protection, the population has begun to rebuild (NMFS 2006), but assessing population status is difficult without standard time-series data. Commercial and recreational catch statistics, which are typically used in stock assessments, are considered to be unreliable for the goliath grouper in USA waters (NMFS 2006, Porch et al. 2006). Instead, indices of abundance considered in the most recent status assessment (NMFS 2006) were developed using a set of logbook records of a single diver in south Florida (1982 to 2002) (Porch \& Eklund 2004), surveys conducted by volunteer divers organized by the Reef Education and Environmental Foundation (1993 to 2002) (Porch \& Eklund 2004), catch and effort data collected in the Everglades National Park creel fishery for juvenile goliath grouper (1973 to 1999) (Cass-Calay \& Schmidt 2003), and anecdotal estimates of population change observed by 9 individual divers and anglers who were present in the Florida Keys before the early 1960s (Porch et al. 2006). Models based on these data sets suggest that the goliath grouper spawning stock biomass was reduced to 5 to $10 \%$ of virgin levels before the harvest ban in 1990 (Porch et al. 2006).

The goliath grouper population in South Florida has increased since protection in 1990 and is thought to have reached 31 to $36 \%$ of its pristine population biomass (NMFS 2006). Based on these recent trends, Epinephelus itajara has been reclassified to be no longer a species of concern in US waters (NMFS 2006). However, the reference points for recovery that were used to support reclassification were developed using data beginning in the 1970s and 1980s along with questionable assumptions, namely that (1) the population was in a pristine state in 1950, and (2) the most severe declines occurred in the 1980s (NMFS 2006, Porch et al. 2006). While it is clear that the E. itajara population was severely depleted by the late 1980 s, few data exist to support assumptions about earlier changes. Therefore, historical data are needed to more accurately determine reference points for modern status assessments. In the present study, 2 new sets of historical data were analyzed: (1) photographic data from Key West charter boats (1956 to 1985) and (2) newspaper articles from the 'Key West Citizen' (1923 to 1977).

\section{MATERIALS AND METHODS}

Historical photographs. A series of photographs of large 'trophy' fish landed at the Key West, Florida docks between 1956 and 1985 was preserved in the
Monroe County Library's historical archives. These photographs contained information on the species composition and size structure of the landings of the largest reef fish before ecological and fisheries-dependent data began to be collected. Photographs were taken of fish caught on 2 headboats (large charter boats that carry up to 75 passengers on day trips) operating out of Key West by a single professional photographer, Charles Anderson. In each photograph, large trophy fish were displayed on hanging boards (Fig. 1). Hanging the fish for display represented the process of determining the largest fish caught on each trip, for which a voluntary monetary pool was typically awarded, and provided an opportunity for passengers to pose with their trophies and for captains to advertise for future trips (pers. obs., D. Gallagher pers. comm.). The photographs were both sold to the passengers, many of whom were from out of town, and sent to their local newspapers across the United States in hopes of attracting attention to Keys' fishing (D. Gallagher pers. comm.). Piles of smaller fish below the display board were present in many photographs, further distinguishing the trophies from the average fish caught. Therefore, the trophy fish hanging on display boards in the photographs represented the largest fish caught on any particular day.

Goliath grouper were frequently larger than the passengers themselves and were second in size only to sharks among the fish caught and displayed on these trips. While catching goliath grouper may have been a common occurrence for local Key West fishermen (E. Little pers. comm.), these large fish were likely a novelty to out-of-town anglers who went fishing on headboats and for whom the photographs were taken. Thus, it is likely that goliath grouper were targeted by the headboats throughout all time periods and displayed and photographed when they were caught. The assumption that frequency of display can be used as an indicator of relative availability underlies all analyses of photographic data.

All fish were caught on boats that target coral reefassociated fishes in close proximity to Key West. The distance traveled to the fishing grounds is limited by the speed of the vessel, the hours available for fishing, and the location of the reef. These charter boats take one-day and half-day trips, typically within an hour's travel time of the dock (Gulfstream Fishing Inc. 2007). Thus, the fish displayed in the photographs represented the largest fish taken in a limited area within $1 \mathrm{~h}$ of Key West sampled by the same fishing boats over time using similar gear and methods (Fig. 2).

Photos taken between 1956 and 1960 include dates, so the exact day and year the fish were caught were known. Those taken between 1965 and 1985 did not 

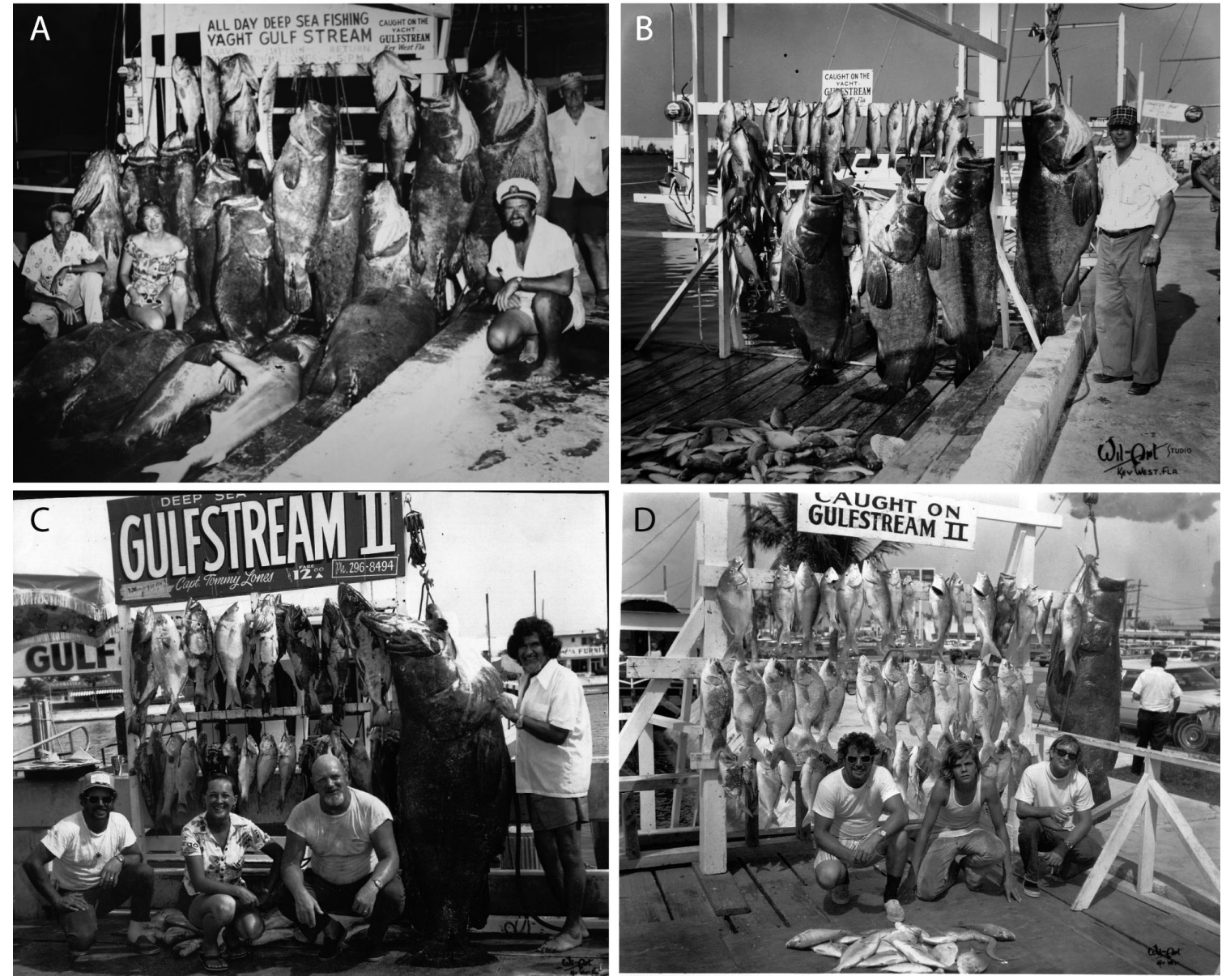

Fig. 1. Examples of photographs from historical archives. Fish caught on the 'Gulf Stream' charter boat on (A) 14 April 1957 , (B) 9 March 1958, and (C, D) between 1965 and 1979

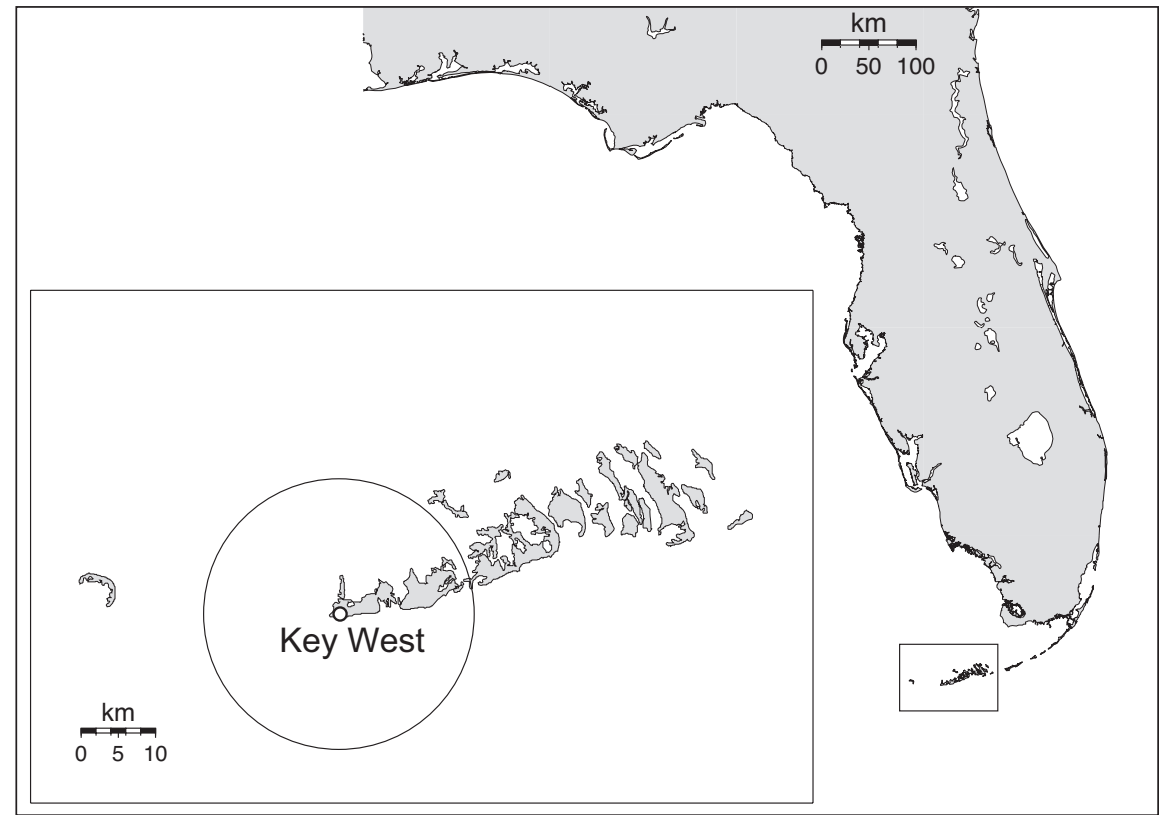

Fig. 2. Study area around Key West, Florida, where headboats operated 
have associated dates so it was necessary to use visual information to date the photos. The most consistent and reliable information to determine the year the photograph was taken is the name of the boat, which was displayed in each photo (Fig. 1). The name of the charter vessel changed in 1980 (T. Hambright pers. comm.), so this dataset was segmented between 1965 to 1979 and 1980 to 1985 . No photos were preserved for 1961 to 1964 .

In order to generate quantitative data from these photographs, it was necessary to standardize photographs across time periods. All displayed fish that could be seen from head to tail and identified were included in the analysis. The total length (TL) of each fish was calculated relative to the height of the hanging board in the photograph (Fig. 3), which was measured in August 2007 and determined not to have changed over time (T. Hambright pers. comm.). If the perspective of the photograph was at an angle, several measurements of height were taken across the display board and averaged. The calculated fish lengths were converted to biomass using length/weight regression parameters (Froese \& Pauly 2007).

A total of 852 fish and 136 ind. of Epinephelus itajara were identified and measured. The data were analyzed in terms of (1) species composition, as both a percent of individuals (number of goliath grouper / number of all individuals $\times 100$ ) and a percent of biomass for each time period (biomass of goliath grouper / bio-

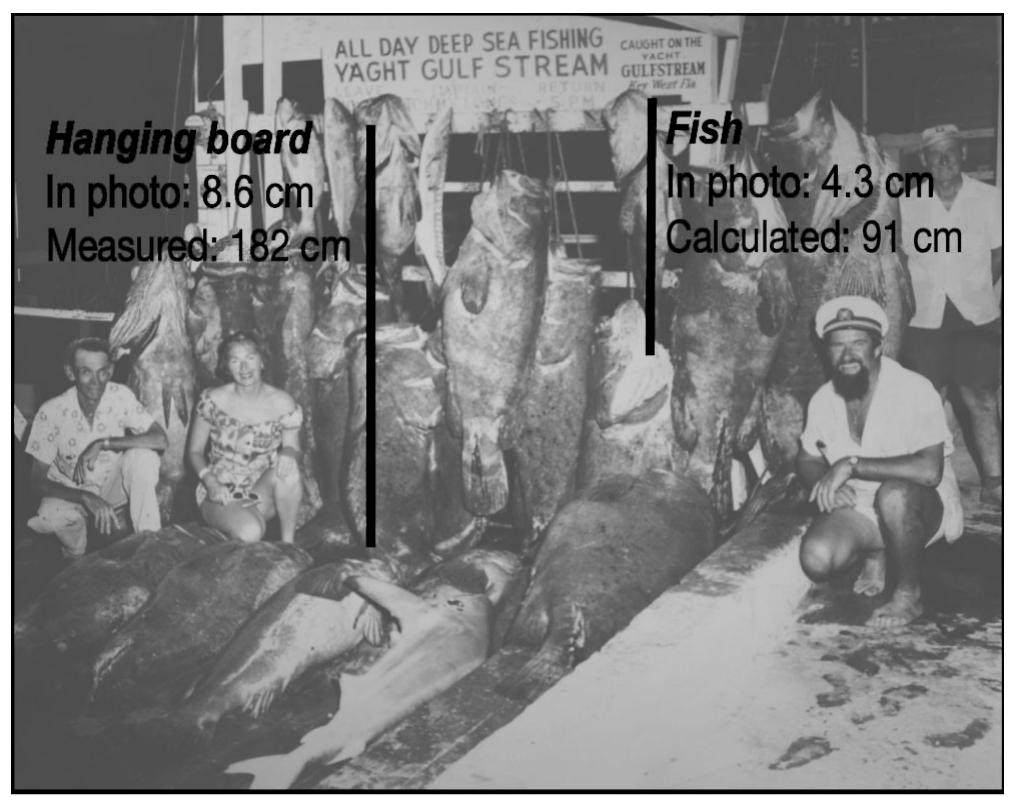

Fig. 3. Method of measuring fish from the Key West charter boats. The wooden structure on which the fish are hung (the hanging board) was measured on site in Key West. The height of the hanging board from the ground to the point at which it attaches to the sign was $182 \mathrm{~cm}$. Fish lengths were then calculated relative to the height of the hanging board in the photo mass of all individuals $\times 100$ ), (2) size frequency distribution of E. itajara within time periods, analyzed using a Kolmogorov-Smirnov test, (3) number of E. itajara caught, landed and displayed on each day of fishing, analyzed using a Student's $t$-test for combined data (1956 to 1960, 1965 to 1979) and a 1-way ANOVA for annual data for years in which photos from multiple trips survived (1957, 1958, 1959, 1960, 1965 to 1979), and (4) biomass of E. itajara caught, landed and displayed on each day of fishing, analyzed using Student's $t$-test for combined data (1956 to 1960, 1965 to 1979).

Historical newspaper articles. Early newspaper articles in the Florida Keys frequently reported large fish that were caught locally, both from docks and bridges, and those landed by boats in the Lower Keys. All relevant articles published in the 'Key West Citizen' between 1923 and 1977 were reviewed and information on the size of the fish and the location the fish was caught was recorded. Data was available for 26 yr during this time period. The weight of the largest fish reported for each year of data was recorded and the relationship between maximum size and year was estimated using ordinary least-squares for pooled data as well as data separated by fish caught from land and offshore. Finally, the percent of these largest fish caught from land vs. offshore was determined for 1923 to 1950 and 1951 to 1977 .

\section{RESULTS}

\section{Photographic data}

Goliath grouper were among the largest fish commonly caught and displayed as 'trophy fish' in historical photographs. In the period between 1956 and 1960, 102 individual goliath grouper appeared in photographs, or $65 \%$ of the biomass and $24 \%$ of the individuals displayed (Fig. 4). Between 1965 and 1979, only 34 individual goliath grouper appeared in photographs, or $32 \%$ of the biomass and $9 \%$ of the individuals displayed (Fig. 4). No goliath grouper appeared in photographs between 1980 and 1985 (Table 1).

Displayed Epinephelus itajara ranged from 75 to $220 \mathrm{~cm}$, and the size frequency distribution varied slightly between the 2 time periods (Fig. 5). The median, first, and third quartile lengths of fish photographed in 1956 to 1960 were 141, 116, and $160 \mathrm{~cm}$, respectively, while those of 1965 to 1979 were 142, 126, and $179 \mathrm{~cm}$, respectively. No 


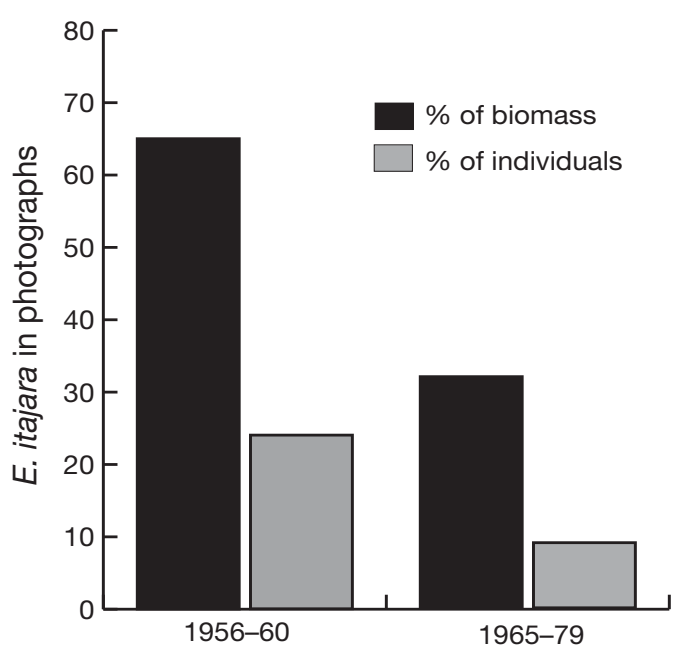

Fig. 4. Epinephelus itajara. Percent of individuals (gray) and percent of biomass (black) of goliath grouper in photographs, 1956-1960 and 1965-1979

Table 1. Epinephelus itajara. Average number of goliath grouper caught per trip, 1956-1979. Data from 1965-1979 and 1980-1985 were grouped because annual data were not available during this time period

\begin{tabular}{|lccc|}
\hline Year & $\begin{array}{c}\text { Number } \\
\text { of trips }\end{array}$ & $\begin{array}{c}\text { Number } \\
\text { landed }\end{array}$ & $\begin{array}{c}\text { Per trip } \\
\text { landings (SE) }\end{array}$ \\
\hline 1956 & 1 & 7 & 7.0 \\
1957 & 5 & 35 & $7.0(2.6)$ \\
1958 & 9 & 24 & $2.9(1.2)$ \\
1959 & 8 & 11 & $2.0(0.7)$ \\
1960 & 13 & 16 & $1.4(0.5)$ \\
$1965-79$ & 35 & 34 & $1.0(0.2)$ \\
$1980-85$ & 2 & 0 & 0 \\
\hline
\end{tabular}

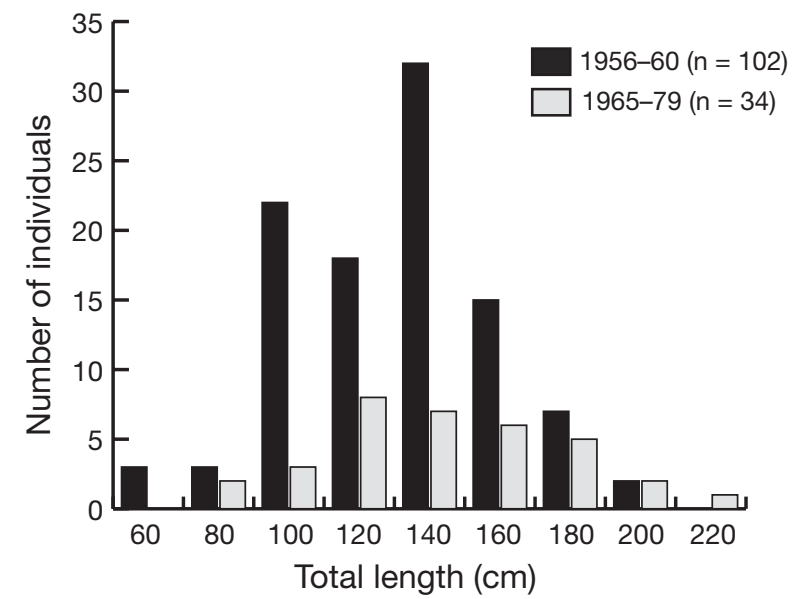

Fig. 5. Epinephelus itajara. Size distribution of goliath grouper 1956-1960 (black) and 1965-1979 (gray) significant difference in the cumulative distribution was detected between the 2 time periods (KolmogorovSmirnov test, $\mathrm{D}=0.22, \mathrm{p}=0.16$ ).

A closer examination of the number of goliath grouper photographed per trip shows a steady decline over time in the numbers of individuals and corresponding per trip biomass. The maximum number of observed individuals photographed on 1 boat was 16 , with an estimated combined biomass of $890 \mathrm{~kg}$. The average annual number of individuals photographed per trip declined significantly for both pooled data for 1956 to $1960(2.8 \pm 0.6$, mean $\pm \mathrm{SE}$ ) and 1965 to 1979 (Table 1 ; $t(69)=2.89, \mathrm{p}<0.01)$ and for annual data for years in which photos from multiple trips survived (Table 1; 1 -way ANOVA $\left.F_{4,65}=7.51, \mathrm{p}<0.0001\right)$. Average biomass of Epinephelus itajara caught and photographed per trip declined significantly $(t(69)=2.2$, $\mathrm{p}<0.05$ ) from $153 \pm 34 \mathrm{~kg}$ during 1956 to 1960 to $69 \pm 15 \mathrm{~kg}$ during 1965 to 1979 .

\section{Newspaper data}

Results from the analysis of the largest goliath grouper reported in the 'Key West Citizen' indicate that the largest goliath grouper were less frequently caught from shore after 1950. In the first half of the time period (1923 to 1950), 69\% of the largest individual goliath grouper were caught from shore, whereas only $8 \%$ of the largest fish were caught from shore between 1951 and 1977 (Fig. 6). These data also demonstrate a significant declining trend in the maximum size of goliath grouper caught in the Lower Keys between 1923 and $1977\left(\mathrm{R}^{2}=0.23, \mathrm{p}<0.01\right.$; Fig. 6). Declines in the size of the largest fish were significant for fish caught from land $\left(\mathrm{R}^{2}=0.32, \mathrm{p}<0.01\right)$, but the trend was non-significant for fish caught offshore $\left(\mathrm{R}^{2}=\right.$ $0.17, \mathrm{p}=0.13)$.

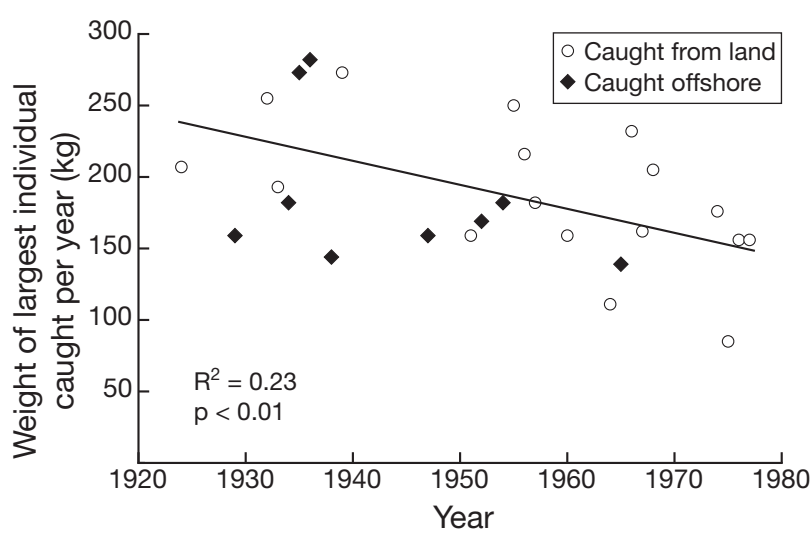

Fig. 6. Epinephelus itajara. Change in maximum weight of goliath grouper 1923 to 1977 reported in the 'Key West Citizen' 


\section{DISCUSSION}

Photographic data show that in the 1950s, boats often returned with large numbers of goliath grouper, the combined biomass of which likely outweighed that of the passengers on board on many days. The decline in absolute and relative abundance of goliath grouper in photographs of Key West trophy fish suggests that local population declines occurred between 1956 to 1960 and 1965 to 1979 . These could be due to changes in fishing practices, rather than changes in abundance. However, it is unlikely that goliath grouper were targeted or photographed less frequently after 1960, since goliath grouper remained an important sport fish until the closure of the fishery in 1990. This was as true for boat-based fishery as for spear fishermen. Moreover, goliath grouper continue to be caught and released by anglers (Cass-Calay \& Schmidt 2009, this Theme Section). Goliath grouper are among the largest reef fish, so it is very likely that they were photographed as trophy fish at least as frequently as other species, and likely were photographed whenever they were landed by the headboats. Thus, declines in the abundance of goliath grouper in photographs relative to other species, as well as the decrease in per-trip landings between 1956 and 1979 suggests early and significant population declines of goliath grouper in the vicinity of Key West. No goliath grouper appeared in photographs between 1980 and 1985, which could be due either to this localized depletion or to the small number of trips for which photographic data survived from this time period (Table 1).

No significant change in the size distribution of goliath grouper occurred between 1956 to 1960 and 1965 to 1979. This result is surprising, given the fact that the number of goliath grouper caught declined and is likely due in part to the small sample sizes. Size frequency analyses are typically conducted with $>100$ individual fish collected on time scales of $1 \mathrm{yr}$ or shorter (Gulland \& Rosenberg 1992), so that samples of 102 ind. over $5 \mathrm{yr}$ and 34 ind. over $15 \mathrm{yr}$ are not sufficient to represent the size structure of the population. More historical data for both time periods would help to better determine the relationship between size and number of fish caught.

In contrast to ambiguous results from the analysis of size frequency, results from the newspaper analyses suggest that the size of the largest fish declined significantly between 1923 and 1977, and that the largest goliath grouper were less abundant close to shore after 1950. While reductions in the size of the largest fish should not be interpreted as a direct metric of population decline, larger-bodied animals are exploited preferentially (Pauly et al. 1998), so that the size of the largest fish can be an indirect indicator of overall avail- ability (Gulland \& Rosenberg 1992). Declines in size and shifts to catching the largest fish offshore suggest that nearshore depletion of the largest goliath grouper was occurring by 1950 .

Recent genetic research has produced more resolved data showing a strong signal of geographic isolation among individuals (Craig et al. 2009). This work suggests that the status of the goliath grouper should be evaluated more considervatively. Similarly, the historical data presented here suggest that the status of the goliath grouper in the United States should be evaluated more conservatively, given the long history of exploitation relative to the short period of protection. Goliath grouper recovery to date (CassCalay \& Schmidt 2009) is promising, but these results suggest that this population recovery is less significant than implied by current assessments, which indicate that populations have recovered to 31 to $36 \%$ of 'virgin' biomass since protection (NMFS 2006). Biological reference points used in the assessment were derived from recently collected data and based on assumptions that major declines occurred in the 1980s and that the population was in a pristine state in 1950 (NMFS 2006). Given the 7 -fold decrease in the number of goliath grouper photographed per trip between 1956 and 1965 to 1979 , and declines in the number of goliath grouper relative to other smaller trophy fish species, the photographic data suggest that the catch of goliath grouper was declining well before the 1980s. Newspaper data suggest nearshore declines before 1950. Each historical dataset represents a different indicator of abundance, but all suggest decline over long time scales. Taken together, they provide evidence that populations were not pristine in 1950 and were declining well before 1980. Therefore, the assumptions used in models of goliath grouper population status should be reexamined, so that historical baselines are set on a more appropriate time scale, and management should proceed cautiously and continue to protect this valuable and vulnerable species. Particularly because so few time-series data exist for the goliath grouper, both in the past and present, it is essential to include all reliable sources of data in assessing population status and trends. Without historical baselines, restoration targets for many species of historically exploited marine animals are far too low and management decisions are made without a proper ecological context.

Acknowledgements. Thanks to P. Dayton, D. Gallagher, R. Graham J. Jackson, E. Little, B. Neal, K. Rhodes, A. Rosenberg, E. Sala, S. Sandin, G. Sugihara, T. Vardi, S. Walsh and 3 anonymous reviewers for helpful suggestions, and to T. Hambright and M. Richie for help locating and digitalizing historical documents. Funding was provided by the NOAA Preserve America Initiative, Marine Sanctuaries Program, Coral 
Reef Conservation Program, National Centers for Coastal Ocean Science, National Marine Fisheries Service, and the Office of Oceanic Research Cooperative Institute; the US Environmental Protection Agency STAR Fellowship; and the Census of Marine Life History of Marine Animal Populations.

\section{LITERATURE CITED}

Baum JK, Myers RA, Kehler DG, Worm B, Harley SJ, Doherty PA (2003) Collapse and conservation of shark populations in the Northwest Atlantic. Science 299:389-392

Cass-Calay SL, Schmidt TW (2003) Standardized catch rates of juvenile goliath grouper Epinephelus itajara, from the Everglades National Park Creek Survey, 1973-1999. NOAA National Marine Fisheries Service, Sustainable Fisheries Division Document No. SFD-2003-0016, Silver Spring, MD

Cass-Calay SL, Schmidt TW (2009) Monitoring changes in the catch rates and abundance of juvenile goliath grouper using the ENP creel survey, 1973-2006, Endang Spec Res 7:183-193

Craig MT, Graham RT, Torres RA, Freitas MO and others (2009) How many species of goliath grouper are there? Cryptic genetic diversity in a threatened marine fish and the resurrection of a geopolitical species. Endang Spec Res 7:167-174

Dayton PK, Tegner MJ, Edwards PB, Riser KL (1998) Sliding baselines, ghosts, and reduced expectations in kelp forest communities. Ecol Appl 8:309-322

Ferretti F, Myers RA, Serena F, Lotze HK (2008) Loss of large predatory sharks from the Mediterranean Sea. Conserv Biol 22:952-964

Froese R, Pauly D (2007) FishBase. www.fishbase.org.

Gulfstream Fishing Inc (2007) Frequently Asked Questions. www.keywestpartyboat.com/FAQ.html

Gulland JA, Rosenberg AA (1992) A review of length-based approaches to assessing fish stocks. UN Food and Agriculture Organization, Rome

IUCN (2007) IUCN Red List of Threatened Species. www. iucnredlist.org/

Jackson JBC (1997) Reefs since Columbus. Coral Reefs 16:S23-S32

Jackson JBC (2008) Ecological extinctions and evolution in the brave new ocean. Proc Natl Acad Sci USA 105: 11458-11465

Editorial responsibility: Rachel Graham,

Punta Gorda, Belize
Jackson JBC, Kirby MX, Berger WH, Bjorndal KA and others (2001) Historical overfishing and the recent collapse of coastal ecosystems. Science 293:629-638

Lotze HK, Milewski I (2004) Two centuries of multiple human impacts and successive changes in a North Atlantic food web. Ecol Appl 14:1428-1447

> Lotze HK, Lenihan HS, Bourque BJ, Bradbury RH and others (2006) Depletion, degradation, and recovery potential of estuaries and coastal seas. Science 312:1806-1809

McClenachan L, Cooper AB (2008) Extinction rate, historical population structure and ecological role of the Caribbean monk seal. Proc R Soc B Biol 275:1351-1358

McClenachan L, Jackson JBC, Newman MJH (2006) Conservation implications of historic sea turtle nesting beach loss. Front Ecol Environ 4:290-296

> Myers RA, Worm B (2003) Rapid worldwide depletion of predatory fish communities. Nature 423:280-283

NMFS (National Marine Fisheries Service) (2006) Status report on the continental United States distinct population segment of the (Epinepheuls itajara). NOAA NMFS, Silver Spring, MD

Pandolfi JM, Bradbury RH, Sala E, Hughes TP and others (2003) Global trajectories of the long-term decline of coral reef ecosystems. Science 301:955-958

$>$ Pauly D (1995) Anecdotes and the shifting base-line syndrome of fisheries. Trends Ecol Evol 10:430

$>$ Pauly D, Christensen V, Dalsgaard J, Froese R, Torres F (1998) Fishing down marine food webs. Science 279: 860-863

Porch CE, Eklund AM (2004) Standard visual counts of goliath grouper off south Florida and their possible use as indices of abundance. Gulf Mex Sci 22:155-163

Porch CE, Eklund AM, Scott GP (2006) A catch-free stock assessment model with application to goliath grouper (Epinephelus itajara) off southern Florida. Fish Bull (Wash D C) 104:89-101

Rosenberg AA, Bolster WJ, Alexander KE, Leavenworth WB, Cooper AB, McKenzie MG (2005) The history of ocean resources: modeling cod biomass using historical records. Front Ecol Environ 3:84-90

Saenz-Arroyo A, Roberts CM, Torre J, Carino-Olvera M (2005) Using fishers' anecdotes, naturalists' observations and grey literature to reassess marine species at risk: the case of the Gulf grouper in the Gulf of California, Mexico. Fish Fish 6:121-133

Submitted: February 19, 2008; Accepted: October 28, 2008 Proofs received from author(s): February 11, 2009 